\title{
Update on extracorporeal oxygenation in adults
}

\author{
W DEMAJO MD FRCPC \\ Departments of Anaesthesia and Surgery, The Toronto Hospital, University of Toronto, \\ Toronto, Ontario
}

W DEMAJO. Update on extracorporeal oxygenation in adults. Can Respir J 1996;3(6):377-379.

The usefulness of managing adult patients with severe acute respiratory distress syndrome and hypoxemia by means of systems using extracorporeal oxygenation has been questioned. A National Institutes of Health multicentre study, published in 1979, reported survival rates of $9.5 \%$ and $8.3 \%$ in extracorporeally and ventilator managed patients, respectively. Another recent study reports survival rates of $33 \%$ and $42 \%$ in ventilator and extracorporealy managed patients, respectively. None of these differences was statistically significant. Indications for extracorporeal oxygenation may need to be re-evaluated to clarify those cases that would not be manageable with current ventilation strategies and, hence, would merit extracorporeal support.

Key Words: Acute respiratory distress syndrome, Extracorporeal membrane oxygenation, Hypoxemia

\section{Mise à jour sur l'oxygénation extracorporelle chez les adultes}

RÉSUMÉ : On a questionné la pertinence de l'utilisation des systèmes d'oxygénation extracorporelle dans la prise en charge de patients adultes atteints d'un grave syndrome de détresse respiratoire aiguë et d'hypoxémie. Une étude multicentrique du National Institute of Health publiée en 1979 faisait état de taux de survie de 9,5\% lors d'une oxygénation extracorporelle, et de $8,3 \%$ si le patient était ventilé mécaniquement. Une autre étude plus récente fait état d'un taux de survie de $33 \%$ chez les patients ventilés mécaniquement et de $42 \%$ chez ceux bénéficiant d'une oxygénation extracorporelle. Aucune de ces différences n'était statistiquement significative. Il se peut qu'on doive réévaluer les indications de l'oxygénation extracorporelle pour éclaircir les cas où les patients ne pourraient pas être traités selon les approches courantes de la ventilation et, pour cette raison, pourraient mériter une oxygénation extracorporelle.
$\mathrm{S}$ gnificant changes in the management of mechanically ventilated patients have occurred over the years as a result of an improved understanding of the respiratory pathology and physiology of this group of patients without, arguably, a significant decrease in mortality. Historically, mortality of patients with severe acute respiratory distress syndrome (ARDS) meeting extracorporeal membrane oxygenation (ECMO) criteria has been reported to be in the range of $85 \%$ to $92 \%$ (1). Mortality was directly due to hypoxemia or mutiple organ dysfunction secondary to the hypoxemia. It was thus argued that if one could support the patient's oxygenation problems, the lungs would be able to heal, without any residual pulmonary deficit (2). Correction of inadequate oxygenation could be accomplished by the use of an ECMO system. Extracorporeal assist for patients with severe acute respiratory failure who failed to be supported with conventional ventilation techniques was first reported by Hill et al (3) in 1972.

The impact, and hence cost effectiveness, of ECMO has been a subject of debate for a number of years. Gille (4) in 1974 reviewed the worldwide experience with extracorporeal support for ARDS in 150 cases and reported a $10 \%$ to $15 \%$ survival rate; a further extension of this review by Gille and Bagniewski (5) in 1976 reported, likewise, an $85 \%$ mortality. These results prompted a nine-centre prospective study comparing conventional ventilation with ECMO, in severe ARDS, which was reported in 1979 (6). Conventional ventilation was maintained during ECMO. The criteria for selec-

Correspondence: Dr W Demajo, The Toronto Hospital, Eaton Wing 2-211, 200 Elizabeth Street, Toronto, Ontario M5G 2C4. Telephone 416-340-4250, fax 416-340-3659 
TABLE 1

Extracorporeal membrane oxygenation entry criteria: $\mathrm{PaO}_{2}<50 \mathrm{mmHg}$ (repeated three times)

\begin{tabular}{|c|c|c|}
\hline \multirow[b]{2}{*}{ Criteria } & \multicolumn{2}{|c|}{ Entry type } \\
\hline & Rapid & Slow \\
\hline Testing time $(\mathrm{h})$ & 2 & 12 \\
\hline $\mathrm{FiO}_{2}$ & 1.0 & $>0.6$ \\
\hline PEEP $\left(\mathrm{cm} \mathrm{H}_{2} \mathrm{O}\right)$ & $>5$ & $>5$ \\
\hline Qs/Qt & - & $>0.3$ \\
\hline $\mathrm{PaCO}_{2}(\mathrm{mmHg})$ & $30-45$ & $30-45$ \\
\hline ICU (h) & - & $>48$ \\
\hline
\end{tabular}

$\mathrm{FiO}_{2}$ Fraction of inspired oxygen; ICU Intensive care unit; PEEP Positive end-expiratory pressure; Qs/Qt Right-to-left shunt fraction

tion are presented in Table 1. All patients with ARDS were treated, with the exception of those suffering chronic and irreversible disease. ECMO access was veno-arterial with a draining cannula in the inferior vena cava and a return cannula in the aorta; this mode was used because reduction of pulmonary bloodflow was considered to be beneficial in that it decreases right-to-left shunt and allows lower ventilating pressures and pulmonary oxygen concentrations. The survival rates were $8.3 \%$ and $9.5 \%$ for the conventional ventilation and ECMO patients, respectively.

As a consequence of this study, ECMO therapy was given up by most centres. Gattinoni et al (7), however, argued for significant changes in the management of patients treated with ECMO. They postulated that maintaining conventional ventilation in patients with severe ARDS caused additional lung damage because of the high ventilating pressures required and suggested that the lungs should be 'rested'. They also believed that veno-venous bypass would offer advantages by maintaining normal perfusion to the lungs, and hence normal oxygenation of lung tissue and distal airways. They termed their technique low frequency positive pressure ventilation with extracorporeal $\mathrm{CO}_{2}$ removal (LFPPV$\mathrm{ECCO}_{2} \mathrm{R}$ ). It involved ventilation at a rate of three to five breaths/min with positive end-expiratory pressure (PEEP) set at 15 to $25 \mathrm{~cm} \mathrm{H}_{2} \mathrm{O}$ and peak airway pressure limited to 35 to $45 \mathrm{~cm} \mathrm{H}_{2} \mathrm{O}$. In addition, during the expiratory phase of ventilation, 1 to $2 \mathrm{~L} / \mathrm{min}$ of a continuous flow of oxygen was insufflated into the trachea through a narrow gauge catheter, inserted through a side port in the tracheal tube connector. They postulated that arterial oxygenation was governed primarily by the fraction of inspired oxygen $\left(\mathrm{FiO}_{2}\right)$ setting on the ventilator and the insufflated oxygen, while the extracorporeal membranes accomplished carbon dioxide removal. This is not quite the case in the majority of patients in whom both oxygenation and carbon dioxide removal is performed, mainly, through the membranes. The ECMO circuit consisited of two catheters inserted into two veins. Different veins were used in different cases, but the saphenous veins were preferred in each leg. The catheters were fed into the inferior vena cava to different levels; the lower one served as the drainage catheter and the higher was the returning catheter. The draining catheter blood was circulated, by means of roller pumps, through two membrane oxygenators having a total surface area of $7 \mathrm{~m}^{2}$. Aproximately $25 \%$ to $35 \%$ of the cardiac output was circulated through the two membranes. The membrane lungs were connected in series and ventilated with a humidified mixture of room air and oxygen at a flow rate of usually $15 \mathrm{~L} / \mathrm{min}$, achieving $100 \%$ saturation of the blood perfused through the two membranes.

In 1984 Gattinoni et al (8) reported a survival rate of $48.8 \%$ in 43 patients selected by the same criteria as those listed in Table 1. Although this was not a randomized controlled study it certainly constituted a dramatic improvement over the previous reports, in a population of patients that carried a projected mortality of $90 \%$. The Toronto Group reported a survival rate of $22 \%$ in a 10-year review (1976 to 1986) of patients mananged with ECMO and conventional ventilation (9). We have since 1989 had an improvement to $47 \%$ in patients managed with a modified ECMO technique and 'lung rest'. A number of other groups in Europe, adopting the Gattinoni technique, likewise reported a survival rate of approximately $50 \%$. The ECMO technique used by the Toronto group consists of percutaneous insertion of cannulae, 19 and 22 French gauges, respectively, into the internal jugular and the femoral vein. The circulation of blood through the membranes is accomplished by means of a centrifugal pump. We also minimize ventilation during ECMO, although we do not insufflate oxygen via the endotracheal tube. Patients are ventilated at a frequency of four to six breaths/min and the appropriate PEEP level to minimize right-to-left shunting; peak airway pressures are controlled at less than $40 \mathrm{~cm} \mathrm{H}_{2} \mathrm{O}$. As the lungs improve, ventilation is increased and the percentage of the bloodflow through the membranes is reduced.

Gattinoni et al (8) had earlier reported a $77 \%$ survival in severe ARDS after support with pressure-controlled inverse ratio ventilation (PCIRV), followed, if necessary, by LFPPV$\mathrm{ECCO}_{2} \mathrm{R}$. Of the survivors, $57 \%$ recovered after PCIRV alone, without ever requiring LFPPV-ECCO $2 \mathrm{R}$, while $43 \%$ of those managed with ECMO recovered. The work of various authors in the intervening years increased appreciation of the potential adverse impact of ventilation, specifically high pressures and large tidal volumes, and changes in the ventilation management had been introduced. Hickling (10) in 1992 reported increased survival in patients with severe ARDS managed with PCIRV and permissive hypercapnia. These considerations indicated the need for a controlled randomized comparison of PCIRV with LFPPV-ECCO $\mathrm{C}_{2} \mathrm{R}$ to determine the true mortality in severe ARDS and the relative advantages of the two modes of management.

Morris et al (11) in 1994 performed a randomized study comparing PCIRV with LFPPV-ECCO $2 \mathrm{R}$ in patients fulfilling the ECMO entry criteria. PCIRV was delivered according to a computerized program in order to standardize management. The characteristics of the patients were similar in demographics, illness severity and duration, and Apache II scores. They were also comparable in physiological characteristics (Table 2). Similar numbers in both groups were enrolled via the fast and slow entry criteria.

Morris et al reported a survival rate of $42 \%$ in the PCIRV 
TABLE 2

Physiological characteristics at randomization: $\mathrm{ECCO}_{2} \mathrm{R}$ versus PCIRV

\begin{tabular}{lcccc}
\hline & All patients & PCIRV & ECMO & P \\
\hline $\mathrm{PaO}_{2}$ & $57 \pm 2$ & $58 \pm 3$ & $56 \pm 3$ & 0.99 \\
$\mathrm{FiO}_{2}$ & $0.9 \pm 0.02$ & $0.9 \pm 0.02$ & $0.9 \pm 0.02$ & 0.88 \\
$\mathrm{PEEP}$ & $16 \pm 0.8$ & $16 \pm 1.0$ & $17 \pm 1.0$ & 0.97 \\
$\mathrm{C}$ & $20 \pm 2.0$ & $22 \pm 3.0$ & $18 \pm 2.0$ & 0.63 \\
$\mathrm{Qs} / \mathrm{Qt}$ & $0.47 \pm 0.01$ & $0.44 \pm 0.02$ & $0.5 \pm 0.02$ & 0.10 \\
$\mathrm{SaO}_{2}$ & $83 \pm 1.0$ & $84 \pm 1.0$ & $81 \pm 2.0$ & 0.35 \\
$\mathrm{P} \mathrm{peak}$ & $56 \pm 2.0$ & $56 \pm 2.0$ & $55 \pm 3.0$ & 0.29 \\
$\mathrm{PaCO}_{2}$ & $49 \pm 2.0$ & $48 \pm 4.0$ & $50 \pm 3.0$ & 0.19
\end{tabular}

$C_{T H}$ Total thoracic compliance $\left(\mathrm{mL} / \mathrm{cmH}_{2} \mathrm{O}\right)$; ECMO Extracorporeal membrane oxygenation; $\mathrm{FiO}_{2}$ Fraction of inspired oxygen; $P$ peak Peak airway pressure $\left(\mathrm{cm} \mathrm{H}_{2} \mathrm{O}\right) ; \mathrm{PCIRV}$ Pressure-controlled inverse ratio ventilation; Qs/Qt Right-to-left shunt fraction; $\mathrm{SaO}_{2}$ Arterial oxygen saturation (\%). Modified from reference 11

group and $33 \%$ in the $\mathrm{ECCO}_{2} \mathrm{R}$; these were not statistically different. This study confirmed the improved outcome reported for both PCIRV and $\mathrm{ECCO}_{2} \mathrm{R}$ but failed to show any significant advantage in the $\mathrm{ECCO}_{2} \mathrm{R}$ group. The complication rates were different in the two groups (Table 3), and seven patients had to be disconnected from the ECMO circuit, five of whom nonetheless survived. Four patients had significant intrapulmonary hemorrhage and their outcome is unclear. Four patients also had clotting of the circuit, usually a disastrous complication and, again, the outcome of these patients is not indicated.

Some centres, in an attempt to reduce bleeding, which is the most common and significant complication, use heparincoated membranes and treat the patients, before and during ECMO, with antifibrinolytic drugs (12). Maintaining high concentrations of antithrombin III through the administration of fresh frozen plasma is recommended by some authors (13). The Toronto Group uses antifibrinolytic therapy and fresh frozen plasma administration in our patients and have not had bleeding complications in the six so managed.

The study of Morris et al has raised significant doubts as to the additional benefit that can be derived from extracorporeal support and suggests that survival with PCIRV is markedly better than previously reported in severe ARDS

\section{REFERENCES}

1. Montgomery AB, Stager M, Carrico C, Hudson L. Causes of mortality in patients with adult respiratory distress syndrome. Am Rev Respir Dis $1985 ; 132: 485$.

2. Pesenti A, Gattinoni L, Bambino M. Long term extracorporeal respiratory support: 20 years of progress. Intensive Care Digest $1993 ; 12: 15$.

3. Hill JD, O'Brien TG, Murray JD, et al. Prolonged extracorporeal oxygenation for acute post-traumatic respiratory failure. N Engl J Med 1972;286:629.

4. Gille JP. Respiratory support by extracorporeal circulation with a membrane artificial lung. Bull Physiopathol Respir 1974;10:3473.

5. Gille JP, Bagniewski A. Ten years of use of extracorporeal membrane oxygenation in the treatment of acute respiratory insufficiency. Trans Soc Artif Internal Organs 1976;22;102.

6. Zapol WM, Snider MT, Hill JD, et al. Extracorporeal membrane oxygenation in severe acute respiratory failure.

JAMA 1979;242:193.

7. Gattinoni L, Pesenti A, Mascheroni D, et al. Low frequency positive
TABLE 3

Occurrences of major complications of extracorporeal membrane oxygenation in a study by Morris et al (11)

\begin{tabular}{|c|c|c|}
\hline Category & PCIRV & $\mathrm{ECCO}_{2} \mathrm{R}$ \\
\hline \multicolumn{3}{|l|}{ Cardiac } \\
\hline Cardiac dysrhythmia arrest & 2 & 2 \\
\hline Cardiac tamponade & & 1 \\
\hline \multicolumn{3}{|l|}{ Central nervous system } \\
\hline Intracranial hemorrhage & 1 & 1 \\
\hline Cerebral arterial gas embolism & 1 & \\
\hline Cerebral hypoxia depression & 1 & 1 \\
\hline \multicolumn{3}{|l|}{ Peripheral vascular } \\
\hline Extremity ischemia & 2 & \\
\hline Arterial embolism & 1 & \\
\hline Venous thrombosis & 2 & 1 \\
\hline Vasculitis & 2 & \\
\hline Dermatitis & & 1 \\
\hline Hypertension & 1 & \\
\hline Neuromuscular (weakness) & 3 & 2 \\
\hline \multicolumn{3}{|c|}{ Hemorrhage (noncentral nervous system) } \\
\hline Intrapulmonic & & 4 \\
\hline $\begin{array}{l}\text { Packed red blood cells transfusion } \\
>0.8 \mathrm{~L} / \text { day }\end{array}$ & & 10 \\
\hline $\mathrm{ECCO}_{2} \mathrm{R}$ discontinuation & & 7 \\
\hline Circuit clotting & & 4 \\
\hline
\end{tabular}

$\mathrm{ECCO}_{2} R$ Extracorporeal carbon dioxide removal; PCIRV Pressurecontrolled inverse ratio ventilation

patients fulfilling ECMO criteria. It also confirmed the previously reported survival rates in patients treated with extracorporeal support. We believe that some patients presenting with severe ARDS, who cannot be supported with PCIRV on $\mathrm{FiO}_{2}$ of 1 after a PEEP trial, should be treated with extracorporeal support. We define a PCIRV failure as arterial oxygen saturation less than 0.85 and/or venous oxygen saturation less than 0.6, with elevated serum lactic acid. We exclude patients who have any or all of significant chronic system disease, contraindications to the use of anticoagulants, malignancies or immunosuppression. We believe that the criteria for instituting ECMO should be changed so that only patients with evidence of tissue ischemia, as reflected in venous oxygen saturation, serum lactate and hypoxic organ dysfunction, would be treated with this modality.

pressure ventilation with extracorporeal $\mathrm{CO}_{2}$ removal in severe acute respiratory failure. JAMA 1986;256:882.

8. Gattinoni L, Pesenti A, Caspani ML, et al. The role of static lung compliance in the management of severe ARDS unresponsive to conventional treatment. Intensive Care Med 1984;10:121.

9. Egan TM, Duffin J, Glynn MF, et al. Ten-year experience with extracorporeal membrane oxygenation for severe respiratory failure. Chest 1988;94:681

10. Hickling K. Low volume ventilation with permissive hypercapnia in the adult respiratory distress syndrome. Clin Intensive Care 1992;3:67.

11. Morris AH, Wallace CJ, Menlove RL, et al. Randomized clinical trial of pressure controlled inverse ratio ventilation and extracorporeal $\mathrm{CO}_{2}$ removal for the adult respiratory distress syndrome. Am J Respir Crit Care Med 1994;149:295.

12. Aranski SF, Adam DH, Rizzo RJ, et al. Femoral veno-arterial extracorporeal life support with minimal or no heparin. Ann Thorac Surg 1993;56:149.

13. Coagulation factor deficiencies during initiation of extracorporeal membrane oxygenation. J Pediatr 1995;126:900. 


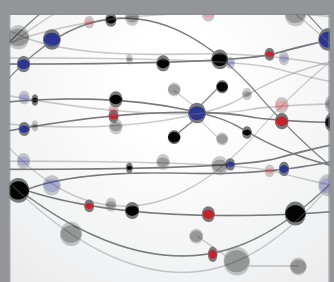

The Scientific World Journal
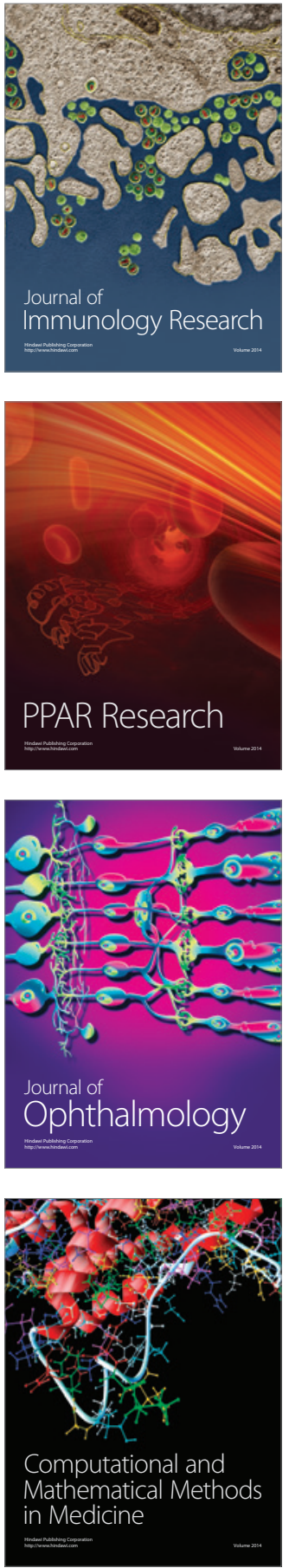

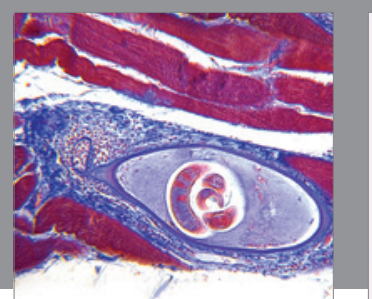

Gastroenterology Research and Practice

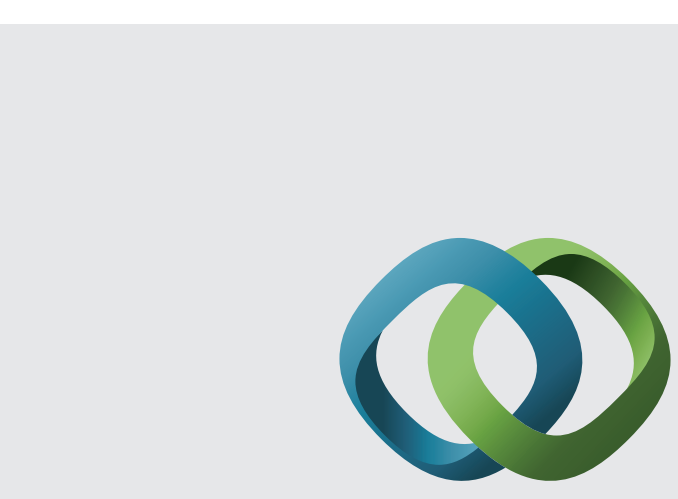

\section{Hindawi}

Submit your manuscripts at

http://www.hindawi.com
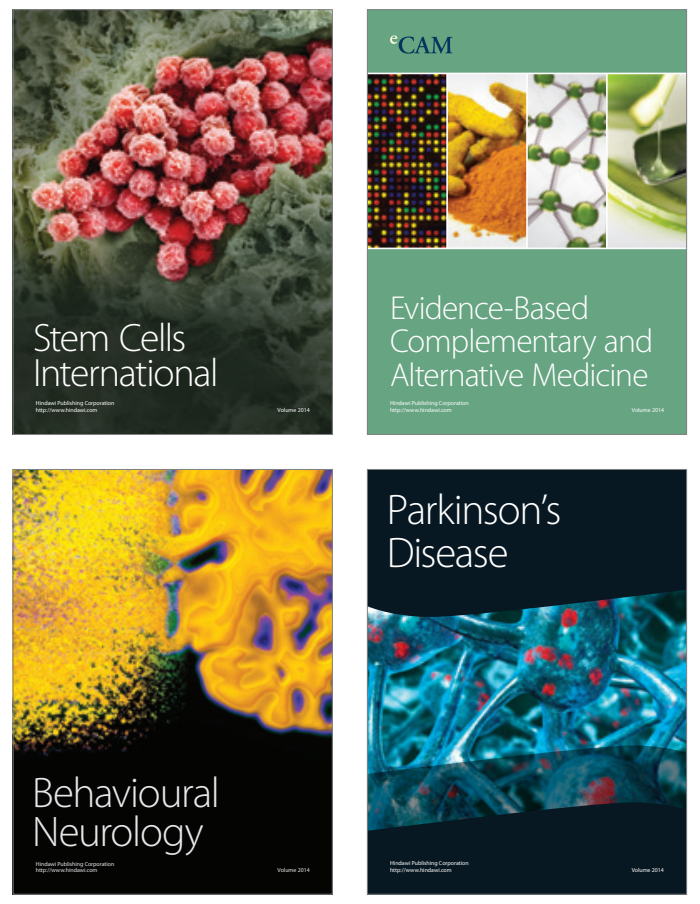
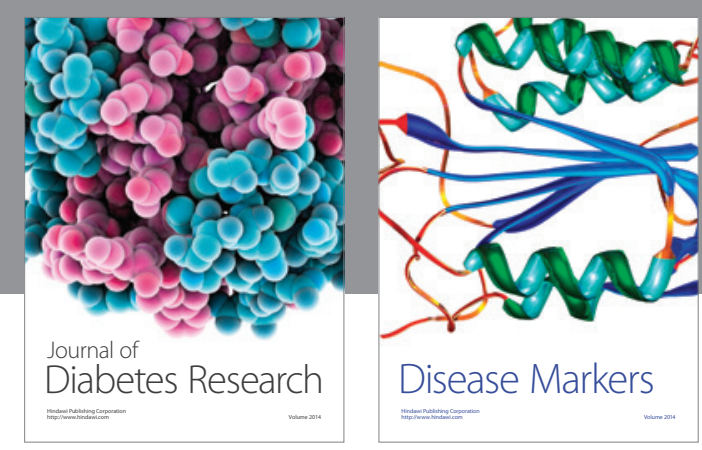

Disease Markers
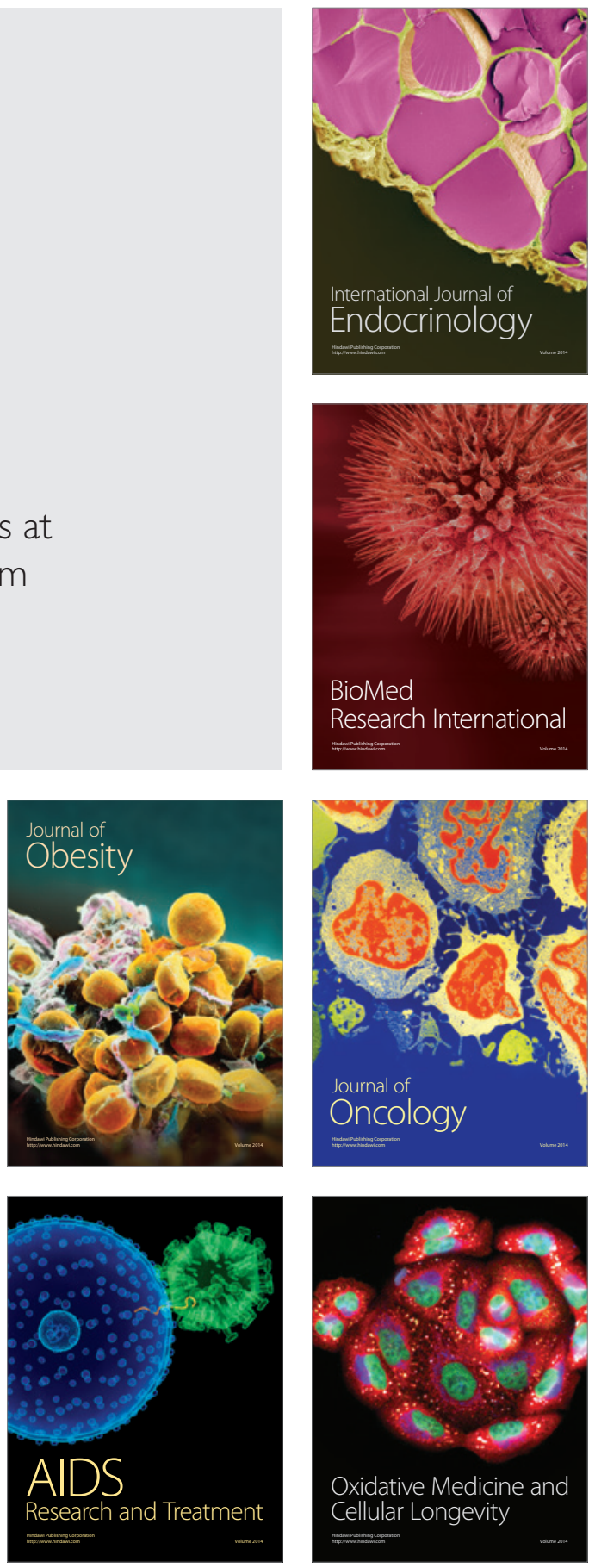